Portland State University

PDXScholar

5-24-2019

\title{
Understanding Dignity Through Survivor Testimony
}

Rachel Fessenden

Portland State University

Follow this and additional works at: https://pdxscholar.library.pdx.edu/honorstheses

Let us know how access to this document benefits you.

\section{Recommended Citation}

Fessenden, Rachel, "Understanding Dignity Through Survivor Testimony" (2019). University Honors Theses. Paper 681.

https://doi.org/10.15760/honors.697

This Thesis is brought to you for free and open access. It has been accepted for inclusion in University Honors Theses by an authorized administrator of PDXScholar. Please contact us if we can make this document more accessible: pdxscholar@pdx.edu. 


\title{
Understanding Dignity Through Survivor Testimony
}

\author{
by
}

Rachel Fessenden

An undergraduate honors thesis submitted in partial fulfillment of the requirements for the degree of

Bachelor of Science

In

University Honors

And

Conflict Resolution

Thesis Adviser

Amanda Smith Byron, Ed.D

Portland State University 


\begin{abstract}
This paper examines the significance of the presence or absence of dignity in the lives of survivors of atrocity. In the aftermath of mass violence and conflict, the honoring of dignity is frequently sidelined or undermined by liberal peacebuilding models in lieu of social and political transformation. These models have been heavily criticized in recent literature for overlooking local context and survivor needs. The necessity for a shift toward humanitarian peacebuilding paradigms has been argued, with calls for the centering of dignity and human rights in postconflict processes. However, the way in which individuals in post-conflict settings experience the honoring or dishonoring of dignity has been insufficiently addressed. This paper seeks to highlight this subject through a review of dignity, the establishment of a positive model for dignity, and an examination of video testimony from Holocaust survivors. This testimony is discussed using the ten elements of dignity identified by Dr. Donna Hicks in her book, Dignity, as a framework for analysis. In my findings, the impact of dignity violations, the potential for human resiliency, and the need for post-atrocity support are illuminated.
\end{abstract}

\title{
Introduction
}

In this paper, I examine the significance of dignity in the lives of Holocaust survivors in order to draw attention to the need for centralization of dignity in post-conflict recovery efforts. Although dignity has been extensively researched within and beyond the field of conflict resolution, humanitarian approaches to peacebuilding, which prioritize the honoring of survivors' dignity, have not been integrated into more prevalent, structurally focused post-conflict peacebuilding models. In order to effectively support the restoration of a community or the rebuilding of a nation in the aftermath of atrocity, consideration for the psycho-social needs of the population is critical. This analysis seeks to understand what survivor testimony may reveal 
about the human experience of atrocity and dignity, and how dignity may support restoration efforts in the aftermath of atrocity.

In order to contextualize this discussion of dignity, the relationship between dignity and peacebuilding must first be addressed. In the foundational principles of conflict resolution, the honoring of dignity is often a fundamental assumption. The essential goals of conflict intervention and transformation, according to Galtung, consist of transforming the energies at the root of conflict and fostering new ways of engagement to create potential for sustainable peace (Mitchell, 2002). Effective engagement is characterized by a cooperative posture (Deutsch, 1994), in which concern for the interests of the self and the other within the conflict are both prioritized. According to Kornelsen (2013), conflict transformation of this nature is the outcome of participants' ability to "look and see" one another through full humanization, as well as the fostering of an "I-Thou" relationship which honors this witnessed humanity. To engage in this way is to recognize and honor the inherent worth and dignity of the other and to centralize this dignity in the process of resolution. This particular prioritization is emphasized in scholarly literature which focuses on the "personal and relational" sphere of transformative conflict resolution, as mediators and facilitators aim to transform dehumanizing perspectives and create spaces in which respectful collaboration becomes possible (Kornelsen, 2013).

\section{Problem Statement}

However, the centrality of this dignity-fostering engagement does not translate to largescale conflicts involving third party interventions. Mediators Bush and Folger, who inspired a movement toward a "transformation" rather than "resolution" emphasis, argue that dispute resolution processes have become organized and institutionalized rather than dynamic and collaborative works (Bush \& Folger, as cited in Mitchell, 2002). In keeping with this trend, post- 
conflict interventions have shifted away from practices which honor and empower conflict participants and instead perpetuate top-down problem-solving approaches (Mitchell, 2002). This system of resolution positions interveners as stakeholders in the conflict as well, with power to manipulate the process in light of their own interests rather than allowing the customs, objectives, and needs of the conflict parties to determine the appropriate path to peace (Mitchell, 2002). By overpowering public interests and enacting a peacebuilding agenda without consideration for local context, peacebuilders fail to honor the dignity of those they claim to help, and the efforts they implement ultimately disintegrate and contribute to unrest (Richmond \& Mitchell, 2011).

Sidelining of dignity is evident in the prevailing approach to post-conflict peacebuilding —liberal peacebuilding. This paradigm "conflates peace with the production of secure and stable neoliberal states, defined by the presence of democratic processes, the rule of law, guaranteed human rights, a social contract guaranteed by a robust civil society, and integration into the global economy” (Richmond \& Mitchell, 2011, p.1). International interveners, including the United Nations and financial donors, impose liberal systems onto nations in the aftermath of conflict as the solution to their national unrest and division. This approach ignores the local context and response, and disempowers communities from determining the path to peace that will effectively transform their society by denying donor support to anyone outside of liberal peace programs. Citizens of such nations may be dehumanized by the international community's deeming them "victims" and the reduction of them into targets for a liberal rescue plan (Byron, 2019). Rather than fostering equality and justice and reflecting the human rights they claim to represent, liberal peacebuilders often reinforce oppressive power structures and limit opportunities for collaboration (Richmond \& Mitchell, 2011). The values proposed in peace 
education—-humanization, dignity, and dialogue—are violated. Humiliation and coercion become part of the strategy for achieving "resolution," and through such means conflict transformation is an impossible goal (Lindner, 2009).

Not only are humiliation, objectification and domination egregious violations, true and sustainable peace cannot be fostered through such an approach. According to Lindner (2009), the conviction that humiliation is unacceptable results from a human rights framework for understanding justice, as those who recognize their subordination and humiliation as unjust violations of their rights feel anger and are motivated to challenge the authorities holding them down. As humanity becomes increasingly connected through globalization, the awareness of human rights and dignity has spread across the world. Individuals who once viewed submissiveness to domination as the path to peace no longer consider this system to be just. "Underlings ... no longer accept lowliness as divinely ordained and non-humiliating” (Lindner, 2009, p. 167), and feelings of humiliation can spark retaliation and revolution. Violent conflict between the oppressed and those in power threatens the safety and stability of combatants and civilians alike.

\section{Response to the problem}

Dignity, the inherent value and worth of every human being, is needed at the center of conflict resolution on every scale, interpersonal to international (Hicks, 2011). Because there has been little research about the role of dignity in post-conflict recovery, further investigation is required to address how dignity may be brought into a central role in the aftermath of large-scale conflict or atrocity. This paper seeks to highlight this need, and refocus attention on the dignity of those who have suffered from atrocity through an examination of the question, "How does survivor testimony reflect the universal need for dignity?” 
In order to clearly define the human need for dignity, I will first review the scholarly literature on this topic to situate a complex understanding of dignity in academic explorations, and then present a specific framework for understanding dignity which was created by conflict resolution expert, Donna Hicks. This framework will serve as a guide as I examine testimony from survivors of atrocity—specifically Holocaust survivors.

The use of testimony in the pursuit of understanding facilitates the humanization which Kornelsen (2013) discusses in his article on conflict transformation. The practice of storytelling provides the foundation for his argument regarding the transformation potential in conflict resolution, as it invites listeners to "look and see" and to find an "I-Thou" connection with the teller through this experience. Storytelling challenges any objectified perceptions of the "other" and opens up minds in a nonthreatening way. It grounds and embodies what might otherwise be a distant and abstracted perspective, and for both the speaker and the listener "it is a means of finding and giving voice to one’s identity and dignity, while recognizing and learning of others” (Kornelsen, 2013, p. 246). The experience of bearing witness to survivors' storytelling surrounding their identities and experiences similarly presents viewers with the opportunity to see the humanity of the speakers, and hopefully to deepen their understanding of dignity in the process.

\section{Literature Review}

In this examination of the literature on dignity, it is important to first acknowledge relevant legal documentation on this subject, specifically the United Nations Universal Declaration of Human Rights. Created in the aftermath of the atrocities of World War II, this document established an international definition and understanding of the basic rights of all human beings, the first of which being dignity. The Declaration's opening line argues that "recognition of the 
inherent dignity and of the equal and inalienable rights of all members of the human family is the foundation of freedom, justice and peace in the world” (Universal Declaration of Human Rights, n.d.). Freedom, justice, and peace are arguably driving ideals of the peacebuilding process, shaping the strategies and goals within it. Whether or not human dignity and rights are recognized and honored in that process influences the success or failure of such goals, a concern I briefly addressed in reference to liberal peacebuilding, and one which informs this examination of dignity.

Scholarly literature on human rights reinforces the theme that awareness and respect for dignity and human rights is critical for freedom, justice, and peace, especially in a peacebuilding context. In her article on the current status of human rights education in peacebuilding practices, Tracey Holland addresses the cruciality of raising awareness of dignity and human rights in the aftermath of violent conflict in order for attempts at restoration and development to be successful (Holland, 2011). Particularly as nations shift from oppressive power structures toward more egalitarian systems in the aftermath of conflict, the fostering of human rights awareness is essential for ensuring that peace and transformation is lasting. Education supports a collective understanding of human rights while empowering individuals in these contexts, many of whom have suffered violations of dignity, to recognize steps they can take to protect their rights from violation. The human rights education process brings together groups of citizens into relationships in which mutual dignity is affirmed and just treatment may be pursued collaboratively. The communal transformation this education supports demonstrates that dignity is a human need in a collective sense for the furthering of safety, security, and justice in society.

Similarly, Evelin Lindner (2009) discusses the transforming impact of the centralization of human dignity and a human rights perspective in conflict resolution processes. She contrasts this 
with methods founded on practices of humiliation, which she defines as the antithesis of dignity, "the enforced lowering of a person or group, a process of subjugation that damages or strips away their pride, honor, or dignity” (Lindner, 2009, p. 169). Examining the consequences of humiliation, she argues that regardless of whether it functions within normalized cultural processes for ranking honor or externally imposed strategies for social change, where enforced hierarchy and subjugation are the means through which a "peaceful" outcome is secured, this peace comes at the cost of the physical and psychological health of the subjected human beings. She outlines contrasting consequences of the emotional pain of humiliation: its potential to fuel repetitive cycles of humiliation and oppressive power over others, or to motivate the pursuit of human rights in an effort to create a new way toward reconciliation. In support of her case for dignity rather than humiliation in conflict resolution she argues that this second path is the only way to a more sustainable peace.

Thus far it is clear that within the scholarly discussion on the pursuit of peace after conflict or atrocity, dignity is identified as critical. Furthermore, looking beyond critical applications for dignity, we see a clearer definition of this concept itself, namely that it stands in opposition to humiliation, and does not allow for the pushing down or oppression of another human. As we move forward, in order to understand the universal need for dignity, we will examine further how this concept and need is defined in various academic disciplines.

In philosophical discussion, we find a similar emphasis to the one Lindner presents in contrasting dignity and humiliation. This negative model of exploring dignity is prevalent in the philosophical discipline, as academics have sought to understand the meaning of dignity and the universal human need for dignity through an examination of the ways in which it is violated-in 
other words, to demonstrate what dignity is not as well as why it is significant (Kaufmann, Kuch, Neuhäuser, \& Webster, 2011).

Sophie Oliver's explanation of dehumanization and its relationship to dignity brings clarity to the logic of negative models for understanding dignity. Oliver (2011) defines dehumanization as "the denial, in part or whole, of the humanity of a person or group of persons" (p. 86), which can take place in both extreme forms and culturally accepted “everyday” ways, as people perceive of and treat others as less than fully human. The process of dehumanization involves a rejection of identity and an exclusion from the broader community, asserting that the dehumanized are no longer within the sphere of moral concern. Oliver argues that dehumanization is both the starting point and product of dignity violations, including "humiliation, degradation, and instrumentalization” (Oliver, 2011, p. 89).

Exploitation of vulnerability, humiliation, degradation, targeted exclusion, and other abuses reveal the significance of dignity to our humanity through the horrors of its denial. Examination of these forms of abuse reveals a clearer vision of dignity as the absence of humiliation, domination, exploitation, etc., but also sheds light on why dignity matters - to treat people abusively is undeniably wrong, violating our inherent worth. Negative analysis such as this has been greatly beneficial for redirecting philosophical debate about the basis for dignity back to the human need.

The philosophical debate on dignity bears acknowledgement, before we return to the subject of human need. Ralf Stoecker (2011) identifies the key historical perspectives on dignity and the current division concerning its basis in his article "Three Crucial Turns on the Road to an Adequate Understanding of Human Dignity.” Historical conceptions of dignity according to Stoecker include “the Greek and Roman heritage culminating in Cicero’s notion of 'dignitas’; the 
biblical conception of man and woman as being created in the image of God; Kant’s Würde as opposed to price” and the legal enactments following WWII.

The Roman notion represents dignitas as a social responsibility for the noble class (Stoecker, 2011). Faith-based understanding of dignity perceives it as divinely bestowed. The philosopher Kant wrote that humanity was set apart from all else based upon reason, and therefore could not be exchanged for any value, monetary or otherwise. Debates about dignity arise from critiques of Cicero and Kant’s descriptions as hierarchical and exclusionary in some cases, and dissension with a religious basis for dignity. Some philosophers have responded to this division by identifying fundamental human rights as the essence of dignity, while others consider it the necessity to have basic human needs met. Questions of origin aside, it is widely agreed that dignity is universal, inherently possessed by every person, and critical to their well-being.

Scholars in social neuroscience, social and evolutionary psychology, and trauma studies have recognized dignity as essential for human health. Neuroscientists Eisenberger and Lieberman (2005) have presented research on the physical implications of emotional pain, such as humiliation. They describe our innate need for connection and the overlap in our brains' pain processing centers for both physical and relational pain, ultimately revealing that broken relational connections can cause measurable pain. Based upon understandings of the biological experience of pain, they argue that our social needs are as critical as other basic needs. Dignity is affirmed and denied in social engagement, reinforcing or damaging connections. The honoring or denial of dignity affects these critical social needs.

Based upon these insights, a positive construct of dignity is important, beyond simply understanding what violates it. Recognizing the necessity for such a model, Conflict Resolution expert Donna Hicks developed one (Hicks, 2011). Based upon conflict dynamics she observed in 
her work, as well as research on critical needs for social connection, Hicks defined ten crucial elements of dignity which provide a pathway for honoring the dignity of others. She distinguishes dignity from needs, saying that we cannot need something we inherently possess. However, the honoring of dignity protects and serves our social needs, and promotes constructive peacebuilding as well.

The elements of dignity include:

1. Acceptance of identity - treating people as equals, without judgement

2. Inclusion - Encourage a sense of belonging in the relationship you share

3. Safety - Ensuring the experience of physical and psychological threat, so others may speak without fear

4. Acknowledgement - Listening attentively and respectfully to others, recognizing their emotions and concerns

5. Recognition - Express perception and support of the contributions of others, demonstrating appreciation

6. Fairness - Behave justly toward others

7. Benefit of the doubt - Assume others are acting from good intentions

8. Understanding - Place value in others' thoughts, listening well in order to see from their perspectives

9. Independence - Promote others' autonomy and sense of control over their own lives 10. Accountability - Take ownership of personal actions and wrongdoing (Hicks, 2011). 
The elements of dignity she has outlined will function as the model for my discussion of the need for dignity in the context of atrocity and the lives of survivors, and have informed my process of bearing witness to the experiences of survivors.

Returning briefly to Oliver's discussion of dehumanization and dignity, it is important to recognize the role of the witness in the experience of dignity. Oliver (2011) stresses the significance of refraining from abstraction and recognizing the embodied or corporeal nature of violations committed against a human being through his or her body. She describes the critical need for both bystander interruption and post-atrocity "witnessing that acknowledges and listens to the lived experience of those who have been excluded and dehumanized. . . to attend to the concrete and individual humanity of the one who suffers” (Oliver, 2011, p. 96). The role of witness in humanization informed my examination of dignity, specifically the methods I used in my analysis.

\section{Methods and Findings}

In order to accomplish this study of the universal human need for dignity in the lives of survivors of atrocity, I researched, read, and watched documentary sources on survivor testimony. To maintain consistency of context, I focused on testimony specific to the duration and aftermath of one atrocity—-the Holocaust. I reviewed a selection of sources including letters, diaries, and recorded video testimony from archives curated by the United States Holocaust Memorial Museum, Yad Vashem, Facing History and the Shoah Foundation.

For the purposes of this examination, I identified video testimony as the ideal source, as I perceived it to offer the deepest insight into the experience of human dignity. This is due to the visual cues video footage contains, such as body language, which illuminates the human 
experience of the survivor more clearly than words alone. While storytelling in any form is a medium for erasing a sense of otherness and promoting humanization (Kornelsen, 2013), storytelling through oral and visual means provides a greater sense of embodiment to the narrative than written works such as letters and diaries (Oliver, 2011). This more sensory form of witnessing increases the experience of humanization and imparts the storyteller's grief, joy, hesitation, anger, and passion to the listener, representing the human experience in greater fullness.

Given the significance of embodiment within the source material, it is important to acknowledge the inability of this written analysis to capture the embodied and deeply humanized portrayal of survivors that they themselves present in video documentaries. Additionally, as someone without direct experiential or familial ties to the Holocaust, I am limited in my understanding of the atrocities which survivors endured, and have never experienced such suffering. With an awareness of these limitations, it is greatly important to me that in reflection upon and assessment of survivor's lives and stories I do not instrumentalize their stories for my own purposes, or perpetuate a denial of their dignity in any way.

In the process of witnessing and examining selected testimonies, my method of assessment consisted of notetaking and coding of survivors' stories, emotions, expressiveness, and points of emphasis as relating to one or more of Hicks' ten elements of dignity. I observed these elements as themes within each testimony—some collectively experienced and others uniquely expressed in the individual's life-illuminating ways in which dignity was violated, personally claimed, honored by others, or given to others through the survivors' words or actions. Within the survivor narratives, elements of dignity were manifested in the facts which each presented to describe their life experience, the highlighting of the moments most painful to them, and the description 
of their means of survival (along with what I interpreted to be key forces sustaining them through the atrocity of the Holocaust).

Acknowledgement of the limitations to this examination's validity is needed, and, to this end, the small selection of subjects must be addressed. I have based my analysis on the testimony of only three survivors, all of whom are Holocaust survivors. Their video testimonies portray their memories of past events at the time of the documentary recording. Further testimony sources and analysis would be greatly beneficial in verifying the validity of my claims and deepening understanding of the significance of dignity in the context of atrocity.

The Survivors

Before examining each element of dignity and the way it was portrayed within the testimonies, I will introduce the survivors who have shared with us their stories, and who have therefore provided the foundation of this work and illumination to the subject of dignity — Gerda Klein, Nechama Schneorson, and Samuel Steinberg.

Gerda Klein was born in the year 1924 in Bielsko, Poland to a Jewish family (Bobrow \& Klein, 1995). She was the youngest child and had one older brother, and was close with all of her family members but especially her father. Her family was forced into a ghetto, and later split apart. She was forced to labor in five different concentration camps throughout the war and was among a group of women abandoned on a march at the end of World War II. Of her family members, she was the only one to survive the Holocaust.

Nechama Schneorson was born in 1929 in Kovno, Lithuania, also to a Jewish family, and she had three sisters (Rettinger \& Schneorson, 1995). Her family was also forced into a ghetto before they were separated and sent to concentration camps. She was forced to labor in the German 
camp, Thorn, and later in its subcamp as well. As the war neared its end Nechama and the other women in her camp were forced to march, and the Germans abandoned them in a forest at the end of the war. Of her family, only Nechama and her oldest sister Zlata survived the Holocaust.

Samuel (Sam) Steinberg was born in 1928 in Tomaszów Mazowiecki, Poland, to a Jewish family, and he grew up in a Jewish community (Stulberg \& Steinberg, 1995). He had two older siblings - a brother and a sister. Their hometown was turned into a ghetto, and he labored there until its final liquidation. He survived through three concentration camps and a death camp. Of all of his family members, he was only one who remained alive at the end of the war.

Throughout the viewing of these testimonies, I observed that certain elements of dignity_acceptance of identity, safety, and fairness—-were unequivocally denied in all survivors' stories. Interpreting that these dignity violations were collective to the Jewish experience, I have discussed them first and assessed the ways in which they were experienced in Gerda's, Nechama's, and Sam's lives. The presence, absence, and significance of other elements of dignity are referenced to varying degrees in the survivors' narratives. These remaining themes will be discussed in relationship to the individual whose story most strongly represented them.

\section{Acceptance of Identity}

Hicks describes the first element of dignity, acceptance of identity, as deeply connected to human social and emotional needs and as grounded in a recognition of equality. Acceptance of Identity, she writes, requires one to "Approach people as neither inferior nor superior to you ... interact without prejudice or bias” (Hicks, 2011, p. 25). In the context of the Holocaust, the identities of Jews and some other minorities were not only rejected, judged, or viewed as the basis of prejudice, but were criminalized, labeled as sub-human, marking Jews as targets for the 
unspeakable atrocities they endured. Forming an understanding of the dishonoring and despising of identity that Jews faced is critical at the start of this discussion surrounding survivors' experience of dignity. Lack of identity acceptance serves as the baseline experience of life in Germany and German-occupied land, and therefore, it is present in each of the survivors' testimonies.

Survivors Gerda, Nechama, and Samuel convey memories in which they faced confiscation of their possessions, were forced to move from their homes into small apartments, and were confined to ghettos because of their Jewish identity, steps which reflect Germans' system of otherizing and separating Jews from the rest of society. As the war progressed, they experienced an intensification of identity-based persecution and efforts to strip them of their identities and sense of humanity altogether.

Each of them was ultimately sent out from the ghettos to concentration camps where they labored under severely dehumanizing conditions. In these places their captors attempted to erase their identities by replacing their name with a number. Nechama describes the process in which she was forced to strip and leave her clothes and belongings, "shower" under a bucket of water with other women, and then take clothes from a pile which others had left behind (Rettinger \& Schneorson, 1995). She was then given a number for identification purposes. Items which connected her to her past life were gone, along with the name which affirmed her personhood. Sam also relayed the memory of his assigned number, and the loss of personal identity that came with it. He said, “My name disappeared and I became ‘B-1840’” (Stulberg \& Steinberg, 1995, 28:37). The erasure of names and the stripping of everything which was personal to them demonstrate how drastically this element of dignity, the acceptance of identity, was violated. 
Building upon the previous findings relating to identity, safety was an additional element of dignity which was universally violated for the Jewish community. In accordance with the unfolding Nazi agenda to annihilate Jews (Hayes, 2018), psychological and physical threats against them escalated. In this environment, experiences of safety were the exception not the rule. Gerda, Nechama, and Sam each described the ongoing threats of abuse, torture, and death they experienced during the Holocaust. However, they each articulated brief havens of safety within this dangerous period as well.

Gerda describes the continuous threat of punishment she faced at the labor camps in which she worked (Bobrow \& Klein, 1995). Those who failed to work at the demanded speed or properly carry out tedious and strenuous tasks were at risk of punishments, including being sent to Auschwitz. In some camps guards were delighted in beating workers over slight mistakes. She describes one such man as a "sadist” and declines to discuss her own experience of beatings.

Gerda had one German supervisor though, who was secretly very kind to her workers. Gerda expresses immense gratitude for this woman, who she says "saved [her] life” (Bobrow \& Klein, 1995, 1:07:18). This took place at a time when Gerda was very feverish and ill and unable to work; her supervisor allowed her to stay in the barracks and rest, however, this gift turned to threat when a cruel inspector arrived to ensure that all of the girls were working. He was notorious for his brutality, and in order to spare Gerda from his wrath, her supervisor found her and snuck her into the factory where she managed to work and avoid further physical harm (Bobrow \& Klein, 1995). Psychological danger, of course, was ever-present.

Nechama vividly describes the physical and psychological violations of safety experienced in her hometown, Kovno, upon the German invasion (Rettinger \& Schneorson, 1995). The shift from safety into danger was a startling one, as she was on her way home from summer camp 
when bombs began falling in the streets. She and her sister were running to reach their home, through "nonstop, violent bombing” (3:22). The terror of the experience impacted her parents just as deeply—-their fear at their children’s fate left them “completely destroyed” (3:29). Violations of safety continued throughout the war. However, Nechama remembers brief periods of safety near the end of the war, when she found a way to hide in a German family's home during the work day. She earned food by working for them, thereby mitigating the pain of her malnourishment. Her oasis of safety was fragile just as Gerda’s was. If the wrong German saw her conduct, she would be violently punished. Indeed, she experienced this once when sneaking back into camp.

In his testimony, Sam shares that his loss of safety began with bombing near his village as well (Stulberg \& Steinberg, 1995). His family gathered their belongings and attempted to flee before the Germans arrived on foot. He describes their journey as walking toward the "wall of flame” along the roadway (11:18). They soon realized that escape was futile—-the Germans arrived quickly, and Sam family and other townspeople returned home. Danger in the ghetto manifested as people were shot and lay dead in the streets. In concentration camps the risk of death by Nazi murder was constant as well in his experience. Those who were not actively killed struggled to hold on to life amidst deprivation of food.

The individual Sam describes as his protector presents a complicated case (Stulberg \& Steinberg, 1995). This German man, in the camp due to his criminal past, took Sam under his wing, and treated him as a mentee. Remembering him, Sam says, “He...never mistreated me. He gave me food ... It's a difficult question to say, but I'm going to talk about it anyway. He definitely tried to take advantage of me sexually, but never forced himself on me” (34:53). He goes on to describe contrasting incidents in which the man coerced him into one behavior but 
respected his refusal in other acts. Given the severity of other dangers around him, Sam experienced this man as a source of safety. In other circumstances he may not have perceived him in this light due to the psychological threats he represented. Regardless, Sam's vulnerability in the truth of his perception and experience is very powerful to witness.

\section{Fairness}

Honoring dignity through fairness, Hicks writes, requires one to "treat people justly, with equality ... [and] without discrimination or injustice” (Hicks, 2011, p. 71). During the Holocaust, treatment of Jews and targeted minorities was entirely founded in discrimination and injustice. Gerda’s, Nechama’s, and Sam’s circumstances were indisputably unfair.

Each shares facts and stories from their life which are illustrative of this. Gerda speaks of a period in which she was deprived of food for four days while German guards and soldiers forced her group to march away from their camp (Bobrow \& Klein, 1995). Nechama testifies to horrifying conditions during the instigation of German occupation of Lithuania, when all the people from her city were rounded up and confined in a guarded area for a week:

If [deprivation of water and facilities] wasn't enough, almost every night, Germans and Lithuanians used to come in and take out women, younger women, rape them, sometimes throw them back, and sometimes you never saw them again. . . Seven days and seven nights, we struggled there, to be together and hide each other. My mother was constantly sleeping over my oldest sister, to cover her so they shouldn't see her. And this is how she escaped from that disaster, not to be raped there. (Rettinger \& Schneorson, 1995, 6:13)

Sam struggled to find words for the discriminatory and oppressive conditions in which he lived, where men were forced to work until they died, or became ill, at which time they were sent to be 
murdered in incinerators (Stulberg \& Steinberg, 1995). “How to describe misery like this? It’s indescribable,” he says. (46:53). In the face of such abuse and injustice, the claiming of fairness is not possible. While survivors held fast to dignity through other elements, the fundamental unfairness of their lived experience could not be erased.

\section{Inclusion}

Transitioning toward a more individualized discussion of the remaining elements of dignity, I observed that Nechama Schneorson's testimony portrayed themes of inclusion. As Hicks’ describes the need for a dignity that fosters inclusion, she relates this element to the psychological need to belong (Eisenberger \& Lieberman, 2005). As the unilateral rejection of Jewish identity and the relentless injustice and violence inflicted upon these individuals demonstrates, the public sphere under Nazi rule did not support Jewish inclusion or belonging. However, in spite of the constant threats they faced, survivors continued to provide and experience inclusion and belonging within their families and communities in ghettos, and through connections in concentration camps as well. The claiming of dignity in the form of inclusion was emphasized in Nechama’s testimony about her experiences of endurance and resistance under Nazi oppression (Rettinger \& Schneorson, 1995).

Nechama describes the memory of her grandmother being separated from the rest of their family and taken with a crowd of people out of the ghetto (Rettinger \& Schneorson, 1995). That night, those within the ghetto heard the sound of unremitting gunshots. Her grandmother, along with 9,200 others, was murdered and burned in an act which she says "broke down the ghetto in the most horrible way” (11:16). In the face of constant threat of brutality, her family drew closer together. She remembers her parents' attempts to find clarity and a way forward for their family in the aftermath of her grandmother’s loss. In her memory, they imparted a vision to their 
children in the following way: "We have to stick together, and whatever happens, we will try to die together, so that none of us should be left alone. But this was the only dream we had; if we have to die, that we should die together” (11:29).

Even if Nazis refused them dignity in inclusion, Nechama's family founded their sense of belonging in the inclusion they experienced with one another, and they went on to offer this element of dignity to other Jews in the ghetto with them as well (Rettinger \& Schneorson, 1995). Their home became a gathering point for members of their community. She remembers shared laughter and tears, people having children, and getting married, embodying and honoring full human experiences despite the atrocities which Germans and Lithuanian police inflicted upon them. When the ghetto began to be evacuated, neighbors and friends flocked to their home, asking to be concealed in their families' basement. All who could fit were welcomed in and hidden together in the basement until they were forced to leave. Until the moment her family was torn apart, they claimed belonging and inclusion with one another, and in doing so, they honored the dignity within others and themselves. This practice of claiming dignity through connection beyond the bounds of Nazi control persisted in Nechama's time in the concentration camps.

\section{Independence}

A second element through which Nechama claimed dignity was independence. In her discussion of independence, Hicks' call to dignity is, "Encourage people to act on their own behalf so that they feel in control of their lives and experience a sense of hope and possibility” (Hicks, 2011, p. 86). She describes an encounter with an individual who shared about his experience of cruel mistreatment as a political prisoner. In response to Hicks' question about his 
reaction and response to the abusive treatment he suffered, he shares a message he internalized as a child through his mother's teaching: Do not react or crumble under the injury. "You are the one in control of your dignity, not the person hurting you” (Hicks, 2011, p. 87). Even in unfair, unsafe, humiliating circumstances, this man retained a sense of control over himself and his dignity, and Nechama exhibited the same sense of power and independence in similarly oppressive and disempowering circumstances.

Nechama describes independence across the entire community of the ghetto, as people bore their laborious work and poor living conditions and continued to find joy in their lives (Rettinger \& Schneorson, 1995). She says that people adjusted to their new way of life and went on to get married and have children. As conditions deteriorated and they were faced with situations of pressure and limited choice, Nechama’s family modelled independence in impossible moments of decision making. As Germans evacuated the ghetto and demanded that everyone in hiding exit her house or be blown up with it, Nechama’s father spoke to family and friends in hiding, leading the decision that they should choose not to remain in the home to be burned to death. Even as he knew the bleak possibilities before them, he asserted that it would be better to be shot than to burn; in this way the group took control of their response to the circumstances they faced.

In her personal decision making, Nechama also demonstrated bold independence, often in moments when many would feel hopeless and out of control (Rettinger \& Schneorson, 1995). When her family was still together in the ghetto, German soldiers began looking for children to remove them from the ghetto. Her younger sister was a child and at risk of being taken, so her family hid her under a bed. When German officers stormed into their small apartment demanding to know if there were children there, Nechama’s family denied it. The man turned and looked under the bed, seeing where her sister was hiding. He demanded that she come out, and in 
desperation the little girl began clawing at the officer's clothes, pleading with him not to take her, and insisting that she would work and do anything required to stay with her mother and father. The officer shoved her off of him, and at that moment, Nechama took action. She grabbed her sister by the hand and ran out the back of the house. She says that they stayed away from the apartment, and that, for some reason, the Germans decided to leave. Nechama resisted becoming powerless or paralyzed in that situation, and her action ultimately spared her sister from being taken away.

Later, when she and the other women were taken to a concentration camp, she begged to be taken with her mother and younger sister, who were going to be separated from her and transported elsewhere (Rettinger \& Schneorson, 1995). In her testimony, she describes begging the guard, ignoring his refusal and pleading again, before he struck her with a rod until she lost consciousness.

She knew the Germans' capacities of violence and harm, and still she claimed her independence and autonomy, even making risky escapes from the forced labor camp near the end of the war (Rettinger \& Schneorson, 1995). Weary of digging ditches outside the encampment in her state of malnourishment, she boldly escaped one morning into a German home. That day, she begged the German family to allow her to sit there, insisting that she would not ask for food or anything else. They permitted her to remain there for the day. At night, when she made her way back to the camp, a guard saw her and beat her badly. Nechama's spirit was not weakened. She said, "During the night, I picked myself up a little bit, and I said, if this was going to happen to me, I'm going to do that tomorrow again, but he's not going to catch me again” (24:50). In this state of resolve, Nechama followed through with her plan during the following days. Another German family allowed her to work their farm during the day in exchange for food. Every day 
for two weeks, Nechama successfully snuck in and out of the camp with her pockets full of potatoes to share with friends, and she was not caught again. Even with the threat of severe punishment, Nechama took control of her decisions and asserted independence, representing dignity that could not be taken away from her by any means.

\section{Accountability}

In her discussion of accountability, Hicks challenges readers to embody this element by "[taking] responsibility for your actions. If you have violated the dignity of another person, apologize. Make a commitment to change your hurtful behaviors” (Hicks, 2011, p. 89). This is a challenging theme to connect with the testimony I have examined, because none of these survivors witnessed penitent perpetrators taking ownership of the atrocities they committed. Neither were any of them coopted into leadership positions among their communities, supporting the German cause through complicity in atrocity against their own people (Hayes, 2018). I did not find testimony of this nature; however, this did take place throughout the Holocaust. Jewish people were placed in positions in ghettos and camps where their circumstances improved at the cost of their perpetration of harm against other Jews. In many cases, this was the outcome of “choiceless choices,” a term developed by Lawrence Langer to describe the impossible decisions Jews faced under amoral Nazi leadership, where refusal to commit harm could lead to one’s own death or immediate suffering (Hayes, 2018, p. 180). The coercive nature of these conditions and the desperation for survival driving participation complicates an already difficult process of taking accountability for one’s actions.

Although the story she shares does not represent a violation of dignity or directly hurtful behaviors, Nechama demonstrates a willingness to wrestle with questions of accountability in her testimony (Rettinger \& Schneorson, 1995). As discussed previously, her final days in 
concentration camps consisted of her daily escapes and farm work, which left her well-fed in comparison to the starving prisoners laboring for the camp. Her escapes persisted for two weeks, but concluded because the camp shut down and all its residents were forced to march for days on end or face the cruelty of the Germans driving them forward. Nechama acknowledges that she had a strength that others did not because she had eaten well in the days preceding the march. Speaking of that experience, she says, "I was ashamed because my stomach was full” (26:56), as others fainted and died. She was not responsible for feeding them, yet she is cognizant of the unfairness of her privilege in that situation and is willing to acknowledge this subject-which could easily be brushed over in her testimony—with great vulnerability.

Benefit of the Doubt

The next element of dignity, benefit of the doubt, refers to the assumption of others’ trustworthiness and integrity, according to Hicks’ model (Hicks, 2011, p. 75). She relates this theme to Nelson Mandela's commitment to regard the whites who imprisoned and oppressed him without anger or resentment, and his honoring of their humanity and dignity. In the survivor testimony I examined, this theme arose in the stories and reflections of Sam Steinberg, who articulates memories of repeatedly extending the benefit of the doubt to the Germans responsible for his oppression.

Sam's father had lived through German occupation in World War I and was familiar with their cruelty in war (Stulberg \& Steinberg, 1995). He considered their newfound oppression a repetition of the same wartime brutality but had no sense of their capacity to inflict mass atrocity. Sam's perspective echoed his father's, as he viewed the oppressive conduct of the Germans as another example of the brutality which humans inflict upon one another in wartime, and not as indicative of an intention to annihilate Jewish people. In his engagement with German officers he 
offered the benefit of the doubt to them as fellow human beings, taking them at their word without recognizing the manipulative motivations behind their messages.

A prime example of this is a conversation Sam had with a ghetto officer during 1943, when Sam was only fourteen (Stulberg \& Steinberg, 1995). At that time the Germans were beginning the process of liquidating the ghetto with the exception of some workers, and Sam was among those they were to leave behind. On that day, he went out of the ghetto to work in the morning, but was not permitted to go home at night. A German told him that "family members of the workers would be put in a special place and kept safe” (19:08), and Sam believed him. In order to "prove" that this was true, the German took Sam and four other workers into the ghetto at that time to visit those remaining. Through tears, Sam tells of his journey into the ghetto, visiting his mother and sister and reassuring them that the German had promised they would be safe. He promised them that they would all be together again later, as he had been told. Those remaining in the ghetto were not protected, however, but sent on to the Treblinka camp. Sam does not express cynicism as he shares, nor does he scoff at his trust in the German. He was among many, young and old, who extended the benefit of the doubt to those who refused to honor dignity in return. He instead expresses grief at the loss he had not believed to be possible, and speaks with compassion toward himself, whom he calls "little boy me” (21:19).

Listening to Sam's story through Hicks' lens of dignity, his dignity is evident in his own integrity and trust, and his willingness to believe in the dignity and trustworthiness of his enemy. The fact that this was violated demonstrates the continued refusal of Nazi authorities and officers to recognize or honor the dignity of Jews.

\section{Acknowledgement}


Gerda Klein provided significant insight into the three final elements of dignity as she shared interpersonal experiences of acknowledgement, recognition, and understanding. In Hick’s model, the first theme, acknowledgement, consists of the attentiveness, validation, and responsiveness offered in engagement with others (Hicks, 2011, p. 59).

As she shared stories from her life before, during, and after the Holocaust, Gerda expressed memories of acknowledgement which she received and experienced as violated, and the deep impact she felt as this element of dignity was honored and dishonored in her life (Bobrow \& Klein, 1995).

In her early years, she described having numerous non-Jewish friends (Bobrow \& Klein, 1995). The loss of these friends as discrimination against Jews escalated in her town caused her “terribly bitter disappointment” (25:13), particularly the break in her closest friendship with a Catholic girl, also named Gerda. When Jews were forced to wear golden stars identifying them as outcasts, the choice for non-Jews to acknowledge or reject them was explicitly clear. Gerda once walked to the post office, wearing her gold star as required, and saw her Catholic friend. She ran up to her to say hello, but her friend refused to address her, instead saying, “I don’t talk to Jews” (26:14). Gerda calls this “one of the most painful experiences” of [her] life (26:21), and one which she was unable to speak about for decades after the Holocaust.

During Gerda’s years of forced labor in Nazi concentration camps, she endured relentless dehumanization (Bobrow \& Klein, 1995). It was an experience of acknowledgement which she says ultimately "restored [her] to humanity again” (1:54:17). At the end of the war, Gerda and a group of women had been abandoned, and took shelter in an empty barn. Gerda was standing outside the building when an unfamiliar army vehicle drove up, and one of the American soldiers approached her. With great trepidation, she told him she was Jewish, and he replied that he was 
Jewish as well. She says, “Then he asked an incredible question-he asked if he could see the other ladies. Obviously, a form of address we hadn’t known or heard” (1:53:50). He asked if she would be willing to accompany him, and held the door open for her to enter first. His attentiveness and consideration for her dignity were both shocking and incredibly restorative to her after the continuous oppressive treatment she had faced.

Gerda expresses a need to emphasize the absence of support and general lack of acknowledgement that survivors experienced after the temporary humanitarian aid teams departed (Bobrow \& Klein, 1995). “There were no psychiatrists, no psychologists, nobody debriefed us from the trauma of six years, all young girls. There were no support systems. . . worst of all, there was no family waiting” (2:00:50). Gerda says it was the attentiveness and concern, the acknowledgement and understanding of Kurt, the American soldier who approached her that day and whom she later married. She credits him for "putting [her] together” again $(2: 02: 09)$.

\section{Recognition}

In her discussion of recognition, Donna Hicks describes the emotional devastation associated with violations of dignity, as people are treated like they are of no significance (Hicks, 2011). These violations and the emotional cost are woven into Gerda's story as well as Nechama’s and Sam’s, because accompanying violations of identity, fairness, safety, and other elements is a message of the worthlessness of the victim, a failure to recognize the humanness and goodness of those under attack. As such, the violations described above also reflect the violation of recognition, the element of dignity which Hicks relates to validation, appreciation, and praise. 
In spite of the systematic undermining of her worth which she experienced in the Holocaust, Gerda asserts this element of dignity repeatedly in her testimony as she expresses gratitude and praise for many others who positively impacted her life, including and beyond the German woman who protected her (Bobrow \& Klein, 1995). She attempted to find that woman after the war to express her gratitude, but was unable to locate her.

Gerda devotes a significant portion of her testimony to remembering the family members whom she loved so deeply (Bobrow \& Klein, 1995). She describes her mother's giftedness in hospitality and her strength amidst her family’s suffering. She remembers her father, with whom she had a very close relationship, as one who was very devoted to his family and faith. He would leave work during the day to be present for his children's puppet shows, and he took his children on memorable adventures. She speaks of her parents' tenderness to their mothers, who both lived with their family for a time. In the mornings her parents would prepare and bring their mothers tea in bed. She remembers her brother as a brilliant writer and her faithful protector and defender.

Gerda honors her friends in her testimony in similar ways (Bobrow \& Klein, 1995). She speaks with particular fondness and gratitude of Liesel, Susie, and Ilse. In her testimony she recognizes Ilse for an astounding gift—she found a single raspberry in one of the camps and carried it the whole day in her pocket in order to offer it to Gerda as a gift. She makes a point to emphasize and recognize the fellow women in all of her camps for the support they provided one another. She feels strongly that this has not been sufficiently acknowledged, and greatly valued her experience of care that the women around her provided. Gerda’s deep gratitude and expressions of praise honor the dignity of those she loves, demonstrate ways in which family and friends sustained each other's sense of dignity during their suffering, and allows those witnessing her testimony to see her dignity expressed through her humble and generous words. 


\section{Understanding}

The final element of dignity under discussion is understanding. In her invitation to readers to honor dignity through understanding, Hicks says, "Believe that what others think matters. Give them the chance to explain and express their points of view. Actively listen in order to understand them” (Hicks, 2011, pg. 26). Similar to the theme of recognition, this element was unilaterally rejected by the authorities perpetuating atrocities against Jews. However, interpersonal relationships provided space for experience of understanding, which is so critical for our social-emotional needs (Eisenberger \& Lieberman, 2005). As she shared about the relationships she held as deeply meaningful, Gerda describes the significance of dignity through understanding.

From the time she was a child, Gerda valued understanding, and this provided her with a gift in later years of precious family stories which would otherwise have been lost to her (Bobrow \& Klein, 1995). She loved the holidays, when her whole extended family gathered in her home, and she listened quietly as they shared stories and gossip, which they mistakenly assumed was beyond young her comprehension. Her memories of early years and her understanding of family members and her family's legacy was a source of great strength to her during the suffering she later endured.

Gerda placed great value on the perspective and views of her father in particular (Bobrow \& Klein, 1995). She sought to understand his insights, and the messages he imparted to her remained in her mind and guided her actions for years to come. She describes his admonishment not to make decisions during the suffering of wartime which would affect her life once it returned to "normal." She understood this, and took care not to commit herself romantically to a 
friend who was pursuing her, with her fathers’ message in mind. Again, in a more serious situation, she remembered a serious conversation with her father about suicide, and a promise they had made with one another to never take this path out of suffering. In a time of great despair and pain, when she was tempted to end her life, she recalled this understanding between them and persevered. Because of the value she placed in the connections with and perspectives of her loved ones, Gerda managed to draw strength even from memories in a season of relentless oppression. Though in her day to day life her perspective did not matter, and she did not have the freedom to express her point of view, Gerda still found dignity and resolve through the understandings which she held onto from the past.

\section{Findings}

The use of Hicks' model provided a rich framework for examining the presence and absence of dignity in Nechama’s, Sam’s, and Gerda's testimony. I observed all ten themes of dignity within testimony, and have identified three key insights from this analysis.

First, my findings show that certain elements of dignity were experienced as completely violated by all who testified — especially identity acceptance, safety, and fairness. The rejection of Jewish identity was the basis for the further abuses and atrocities committed against them, which exposed them to physical and psychological danger, and indicated the lack of justice for Jews and other targeted minorities. Along with this, they experienced psychological wounding based upon experiences of interpersonal rejection and cruelty; however, the 
identity/safety/fairness abuses in particular were comprehensively described and alluded to throughout all three videos. The survivors' experiences of the described dignity violations were traumatizing. This was made clear through the triggered reactions and emotions expressed throughout the process of testifying. Survivors were moved to tears in some moments of sharing, and some events were too painful to discuss.

The second trend in my findings is the resiliency each survivor demonstrated in claiming dignity despite dehumanizing circumstances. The testimony demonstrated that Hicks' elements of dignity were means through which survivors could sustain a sense of dignity, and each describes doing so in their own way. Nechama's assertion of independence, fostering of inclusion, and acknowledgement of accountability; Gerda’s expressions of recognition, and understanding; and Sam's willingness to extend trust to his enemies through the benefit of the doubt, all represent continued dignity in the midst of the atrocities they endured.

Finally, these survivors' messages demonstrated that short term humanitarian aid was insufficient in providing support in the aftermath of the dignity violations and psychological trauma they experienced. In evidence of this was Gerda's emphatic assertion that after the war, in a great time of psychological vulnerability for her and the girls with whom she was freed, “nobody was there” (Bobrow \& Klein, 1995, 2:00:01). This point begs for more in-depth research in order to illuminate the trends in survivors' experiences of insufficient support, and to examine the forms of support most desired in the aftermath of atrocity. For the purposes of this discussion, Gerda's testimony made clear that ongoing affirmation of dignity in her relationships after the Holocaust represented lifelines which sustained her in a difficult healing process.

\section{Conclusion}


In conclusion, the lack of centralization of dignity in post-conflict peacebuilding reveals concerning potential for dignity violations by those who claim to support and promote processes of restoration. In order to bring dignity into a central role in post-atrocity contexts, both the meaning of dignity and the way in which it is experienced are critically important to understand. The literature on the psychological impacts of violated dignity clearly demonstrates that honoring of dignity is integral to psychosocial health and well-being. A positive framework for understanding the honoring of dignity has been provided through Donna Hicks' model, and this model has proved to be an effective tool for understanding survivors' experiences of dignity.

Survivor testimony revealed, through deeply humanized expression, the traumas and strengths, vulnerabilities and needs of those who have endured severe and relentless dignity violations. Nechama's, Sam's, and Gerda's stories demonstrate that dignity is a central theme in the process of sense-making that survivors navigate in the aftermath of atrocity. While the systematic humiliation and oppression they endured was dehumanizing and violating, each survivor articulated personal and relational experiences of dignity as it was claimed and sustained.

As mass atrocities continue, effective intervention and restoration are essential now more than ever. This work has sought to illuminate, through Holocaust survivors' words, the human experience of and need for dignity, and the psycho-social dimension of the trauma inherent to dignity violations, in the hopes that peacebuilding initiatives will expand their focus beyond merely the structural and political needs of conflict to encompass humanitarian approaches as well. In order to transform a society and cultivate authentic peace, healing and empowerment are essential. Through a humanitarian lens which centralizes dignity, peacebuilding initiatives may 
promote the healing of survivors so that they may be empowered to participate in the transformation of their societies.

\section{References}

Bobrow, L. (Interviewer) \& Klein, G. (Interviewee). (1995). Full Length Testimonies: Gerda Klein [Interview video file]. Retrieved from USC Shoah Foundation website: https://sfi.usc.edu/full-length-testimonies?nid=470

Byron, A. (2019). (Re)Claiming human dignity (Forthcoming). Journal of Transdisciplinary Peace Praxis.

Deutsch, M. (1994). Constructive conflict resolution: Principles, training, and research. Journal of Social Issues, 50(1), 13-32. 
Eisenberger, N. I., \& Lieberman, M. D. (2005). Why it hurts to be left out: The neurocognitive overlap between physical and social pain. In K. D. Williams, J. P. Forgas, \& W. von Hippel (Eds.), Sydney Symposium of Social Psychology series. The social outcast: Ostracism, social exclusion, rejection, and bullying (pp. 109-127). New York, NY: Psychology Press.

Hayes, P. (2018). Why?: Explaining the Holocaust. New York: W. W. Norton \& Company.

Hicks, D. (2011). Dignity: The essential role it plays in resolving conflict. New Haven: Yale University Press.

Holland, T. (2011). Human rights education in peacebuilding: A look at how far the practice has come and where it needs to head. Interdisciplinary Journal of Human Rights Law, 6(1), 103.

Kaufmann, P., Kuch, H., Neuhäuser, C., \& Webster, E. (Eds.) (2011). Humiliation, degradation, dehumanization: Human dignity violated. Dordrecht: Springer.

Kornelsen, L. (2013). The role of storytelling at the intersection of transformative conflict resolution and peace education. Storytelling, Self, Society, 9(2), 237-260.

Lindner, E. (2009). Why there can be no conflict resolution as long as people are being humiliated. International Review of Education, 55(2), 157-181.

Mitchell, C. (2002). Beyond resolution: What does conflict transformation actually transform? Peace and Conflict Studies, 9(1), 1-23. 
Oliver, S. (2011). Dehumanization: Perceiving the body as (in)human. In P. Kaufmann, H. Kuch, C. Neuhäuser, E. Webster (Eds.), Humiliation, degradation, dehumanization: Human dignity violated (pp. 85-97). Dordrecht: Springer.

Rettinger, C. (Interviewer) \& Schneorson, N. (Interviewee). (1995). Full Length Testimonies: Nechama Schneorson [Interview video file]. Retrieved from USC Shoah Foundation website: https://sfi.usc.edu/content/nechama-schneorsons-full-testimony

Richmond, O. P., \& Mitchell, A. (2011). Peacebuilding and critical forms of agency: From resistance to subsistence. (Reprint)(Report). Alternatives: Global, Local, Political, 36(4), 326.

Stoecker, R. (2011). Three crucial turns on the road to an adequate understanding of human dignity. In P. Kaufmann, H. Kuch, C. Neuhäuser, E. Webster (Eds.), Humiliation, degradation, dehumanization: Human dignity violated (pp. 7-17). Dordrecht: Springer.

Stulberg, C. (Interviewer) \& Steinberg, S. (Interviewee). (1995). Full Length Testimonies: Sam Steinberg [Interview video file]. Retrieved from USC Shoah Foundation website: https://sfi.usc.edu/full-length-testimonies?nid=463

Universal Declaration of Human Rights. (n.d.). Retrieved from http://www.un.org/en/universaldeclaration-human-rights/ 